\title{
Journey to the top-breaking through the canopy: Canadian experiences
}

\author{
by Elaine Teske ${ }^{1}$ and Bronwen Beedle ${ }^{2}$
}

\begin{abstract}
The authors reviewed the Canadian scene to examine the contribution of women in defining the Canadian forestry agenda and to see what was happening to those women who were advancing to the top and breaking through the canopy. The Canadian forest sector has been and is still a male dominated world. The women who were contacted work in varying jurisdictions-government, industry, academia and consultants. Their perspectives on how the journey to the top was progressing, the challenges faced and the factors affecting this journey are chronicled.
\end{abstract}

Key words: women in forestry, women of influence, role of mentor, barriers, non-traditional career path, women and natural resource management

Les auteurs ont révisé la scène canadienne pour examiner la contribution des femmes dans l'établissement du répertoire forestier canadien et pour voir ce qu'il advenait de ces femmes qui progressaient vers le sommet et dépassaient la cime des arbres. Le secteur forestier canadien a été et demeure un monde dominé par les hommes. Les femmes qui ont été approchées travaillent dans différents domaines - gouvernement, industrie, enseignement et consultation. Leurs points de vue sur la progression vers le sommet, les défis soulevés et les facteurs affectant cette progression ont été répertoriés.

Mots clés: femmes en foresterie, femmes d'influence, rôle de mentor, barrières, cheminement de carrière non traditionnel, femmes et aménagement des ressources naturelles

\section{Introduction}

The role of women in the forestry sector in Canada has changed dramatically over the past 15 years leading into the new millennium. This change has shifted from the more traditional subordinate but supporting role, to one of women moving into management and decision-making.

The authors reviewed the Canadian scene to examine the contribution of women in defining the Canadian forestry agenda and to see what was happening to those women who were advancing to the top and breaking through the canopy. The Canadian forest sector has been, and is still, a maledominated world. The women who were contacted and interviewed work in varying jurisdictions in the forestry sectorgovernment, industry, academia and consultants. Their perspective on how the journey to the top was progressing, the challenges they faced and the factors affecting this journey is the focus of this paper.

\section{Background: A Snapshot of our Women Leaders}

Canada owns $10 \%$ of the world's temperate and boreal forests and is one of the few developed nations still richly endowed with large areas of natural forest. Canada's forests are the products of the dynamic forces of evolution since the last ice age. The forest ecosystem is a fundamental national value that in many ways defines the social, cultural and economic profile of Canada.

\footnotetext{
${ }^{1}$ Director, Marketing and Operations, Canadian Forest Service, Natural Resources Canada, 506 W. Burnside Road, Victoria, British Columbia V8Z1M5. E-mail: eteske@pfc.forestry.ca

${ }^{2}$ Assistant Deputy Minister, British Columbia Ministry of Forests, 595 Pandora St., Victoria, British Columbia V8W 3E7. E-mail: Bronwen.Beedle@ gems1.gov.bc.ca
}

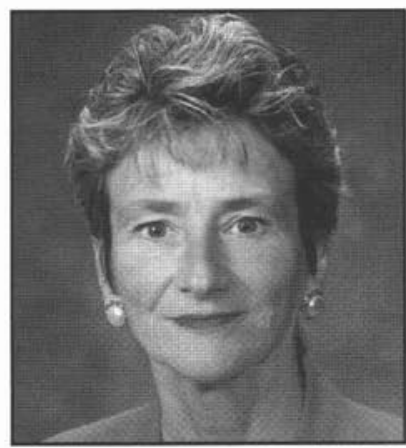

Elaine Teske

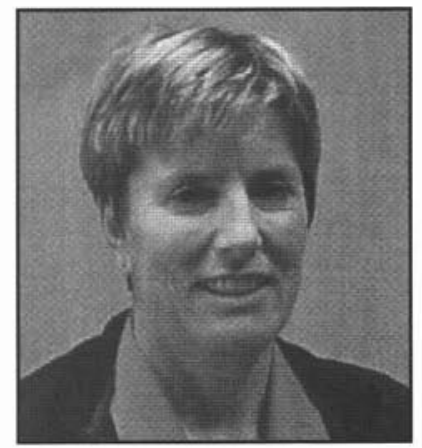

Bronwen Beedle
Utilizing, managing, enhancing and protecting Canada's primary natural resource is a challenge shared by decisionmakers and stakeholders in government, industry, academia and environmental non-governmental organizations (ENGOs). Who are these powerbrokers and policy makers that produce the institutional setting and operational prescriptions for Canada's forests?

The survey population included 83 women in senior positions across Canada, of which 53 were interviewed. The survey was designed to provide information on factors that impacted their journey to the top, the people who assisted them in their journey and the influences that were critical to their movement up the responsibility ladder.

\section{History}

Women have always had a role in the forest sector in Canada but generally, these roles have been under-appreciated and inadequately compensated. A 1983 study on women in the 
forest industry noted that "women have traditionally done the maintenance tasks in the homes and the service tasks in the offices, stores, shops, schools and hospitals in resource communities. In their absence, the forest company employers could not maintain company towns and the overall cost of obtaining a male labour force would sharply increase" (Marchak 1983).

An initial professional entry point for women in Canadian forestry was as research scientists working in federal government laboratories in the 1920s and 1930s (Natural Resources Canada 1998). For many decades lab work remained one of the few areas open to women, and even in 1958 when Francis Wetton became Canada's first female professional forester, women were largely unwelcome either in the woods or in the boardrooms. Today, some 43 years later, only between 5 and $14 \%$ (depending upon the region of the country), of professional foresters are women.

National statistics show that women continue to be underrepresented in the woods, as university students, in academia, in operations and in all facets of the forest sector. According to Statistics Canada (2001), $16 \%$ of those employed in the forest sector today are women, well below the overall average of $45 \%$ for all occupations.

While there are national statistics available that quantify women in the forestry workforce, most of them estimate jobs, salaries and educational data at the operational levellogging and sawmilling and pulp and paper operations. For example, Statistics Canada shows that $12 \%$ of machine operators and related workers in the pulp and paper production and wood-processing component are women. Other data show that $14 \%$ of supervisors in logging and forestry are female ${ }^{3}$ (Hislop 1998).

Nearly two decades later, although there are more women in forestry, and these women are increasingly influential, statistics show that the numbers working in the forestry sector continue to lag well behind other sectors of the economy (Human Resources Development Canada 2001). Statistics from British Columbia's Association of Registered Professional Foresters show that between 1995 and 2000 the percentage of women professional foresters in that province only modestly increased to $14 \%$ from $10 \%$ (J. Marburg, Registrar, Association of BC Professional Foresters, personal communication and Atkinson and MacIvor 2000).

Statistics Canada estimates women account for $36.5 \%$ of management positions across all jobs in 1999, compared with $31 \%$ in 1987 . While there are no statistics on the number of women in executive positions within the Canadian forest sector, a review of corporate publications, university faculty and government agencies confirms that few women hold the most senior of positions within the industry. There are no women Chief Executive Officers in any of the forest companies, although there are several women Vice Presidents. There are several women who lead national industry groups, but of the seven Bachelor-level degree-granting universities in Canada, there are only two female Deans of Forestry. Therefore, the authors have relied heavily on primary data collected through a survey of women working at a senior level in Canadian forestry.

\footnotetext{
${ }^{3}$ Barbara Hislop. "The Role of Women in the Forest Products Industry." Speech given to Canadian Women in Timber Annual General Meeting, September, 1998. Prince George, B.C.
}

\section{Research: Where are the Current Women Leaders?}

So, exactly what are the factors that motivated respondents to seek out opportunities to influence the way forestry is practised in Canada? Despite the dearth of female role models, what enabled these women to reach the upper echelon of their organization? How do women define success and what factors are most important to them in feeling successful? How long did the journey take?

The authors made initial contact in late 2000 with 83 women of influence across Canada, received 53 responses to questionnaires similar to those used by Lalonde (1993), and personally interviewed 16 to clarify information provided. The women contacted are employed in the fields of academia, management positions in government and industry, field operations, education, communications and policy-making. They were not only chosen because of their "senior" positions within their organizations, but also because of their contributions via the unpaid work they do through professional organizations and the sphere of influence they have on the sector as a whole.

Nearly $45 \%$ of the respondents are currently employed in management-related work. Very often, it is combined with other related areas such as policy, finance or program development.

Sixty-eight per cent $(68 \%)$ of the interviewees were between the ages of 41 and 50 and $16 \%$ were between ages 31 and 40 . The remaining $16 \%$ were either in their 20 s or their 60 s. The authors purposefully chose a small sample of respondents in their $20 \mathrm{~s}(2 \%)$, in order to determine factors that might influence the next generation of leaders. The women in their $50 \mathrm{~s}$ and 60 s were considered to be the group who had paid their dues and paved the way for this new generation.

Respondents were asked to rate a number of factors they felt were important in reaching their current position, or where they aspire to be in the future. The three most important factors were education, mentors/risk-taking boss and barriers. In addition, the authors investigated issues faced by women choosing a nontraditional career path. The findings are now examined in more detail.

\section{Findings: Education}

Eighty-five percent of the interviewees had an undergraduate degree, $77 \%$ of which were science degrees, including forestry. The remaining degrees were in varying fields not directly related to the resource sector. According to Statistics Canada, in 1997, 430 students received an undergraduate degree in Canadian forest science programs, of which only $22 \%$ were women. This compares to $13 \%$ women graduates in 1987 (Fig. 1).

Some $55 \%$ of the women responding to the survey who earned undergraduate degrees went on to earn Masters degrees. Half were in fields directly related to forestry, such as biology, genetics, biochemistry, with the remainder divided between those indirectly related to the resource sector such as business administration, project management and public administration, or were in non-related fields. A further $26 \%$ continued on to earn a Doctorate in science-related disciplines.

In addition to university education, continuing education was identified as very important to the respondents; $100 \%$ had taken job-related training above and beyond the formal education they received. Courses in communication, leadership, technical 


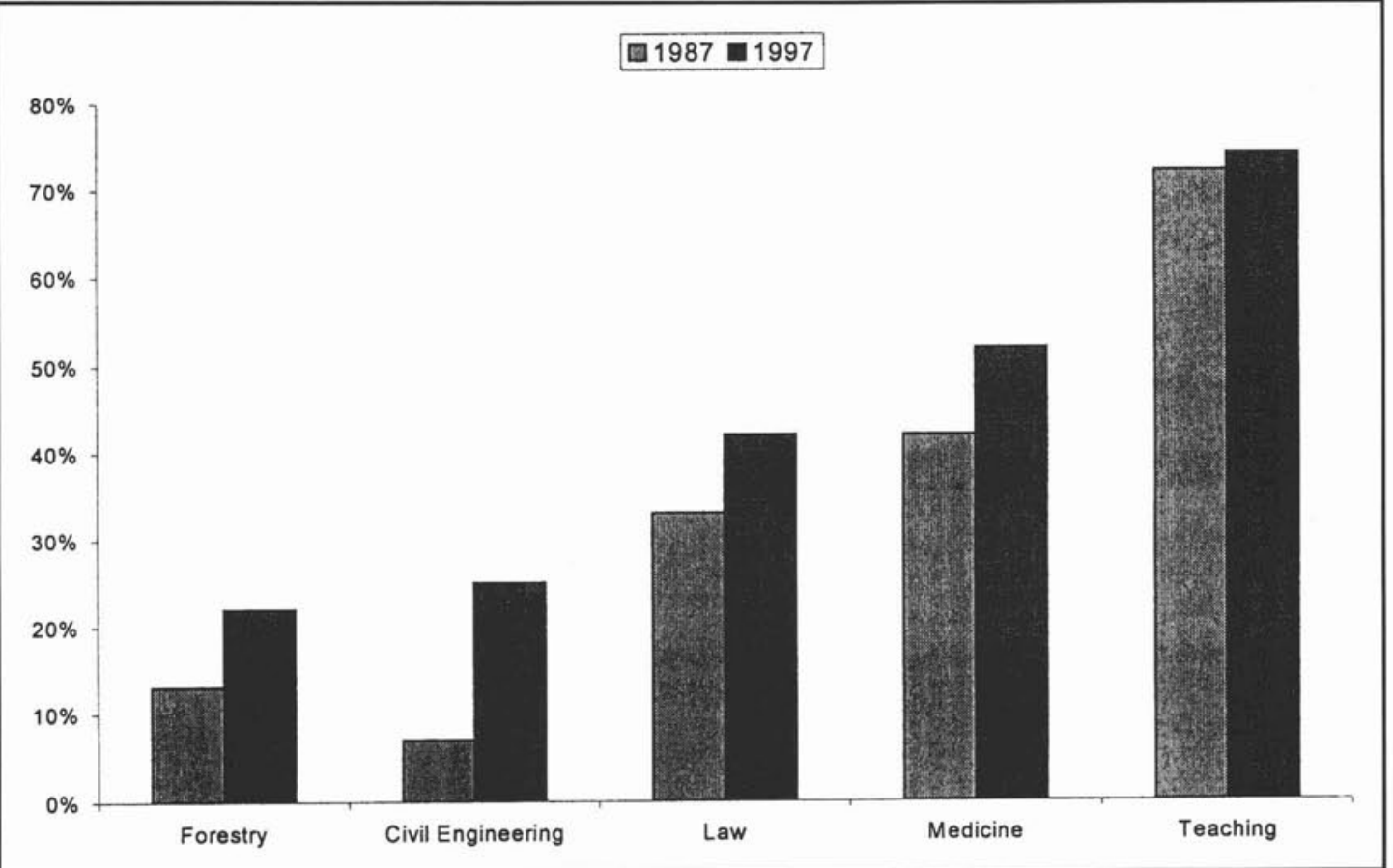

Fig. 1. Percentage of women graduates by discipline-1987 and 1997. (Source: Statistics Canada n.d.)

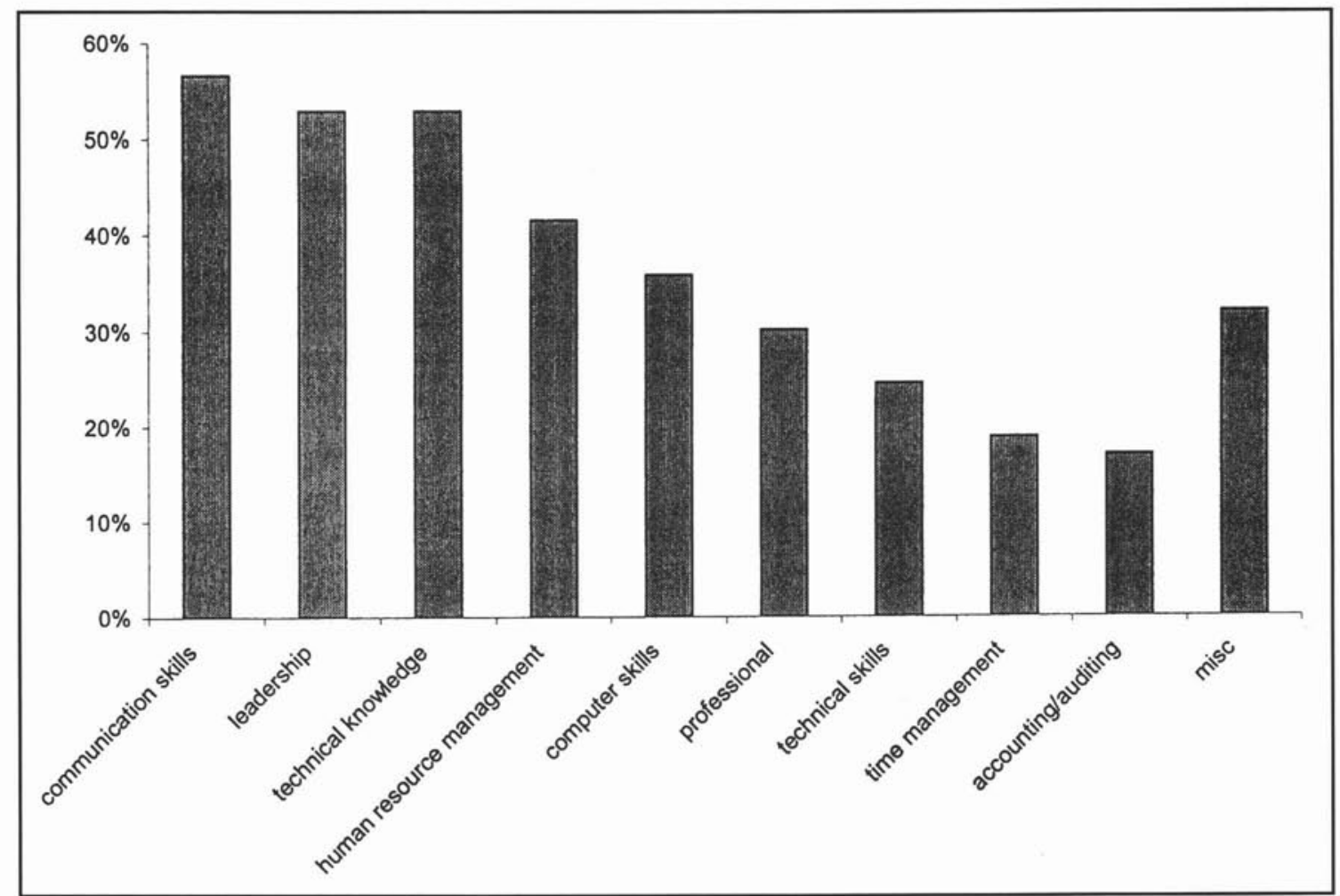

Fig. 2. Continuing education courses respondents have taken.

knowledge and human resource management ranked as the most important and advantageous to subsequent career advancement. In addition, the women felt courses in computer skills, time management, accounting, strategic planning and team building were important to their career and personal development (Fig. 2).

\section{Findings: Mentor}

A mentor is traditionally described as a person who provides guidance and advice via coaching, counselling or tutoring a specific individual towards attainment of a goal. The respondents to the questionnaire also included risk-taking boss in the mentor category. Women ranked them as the most significant 


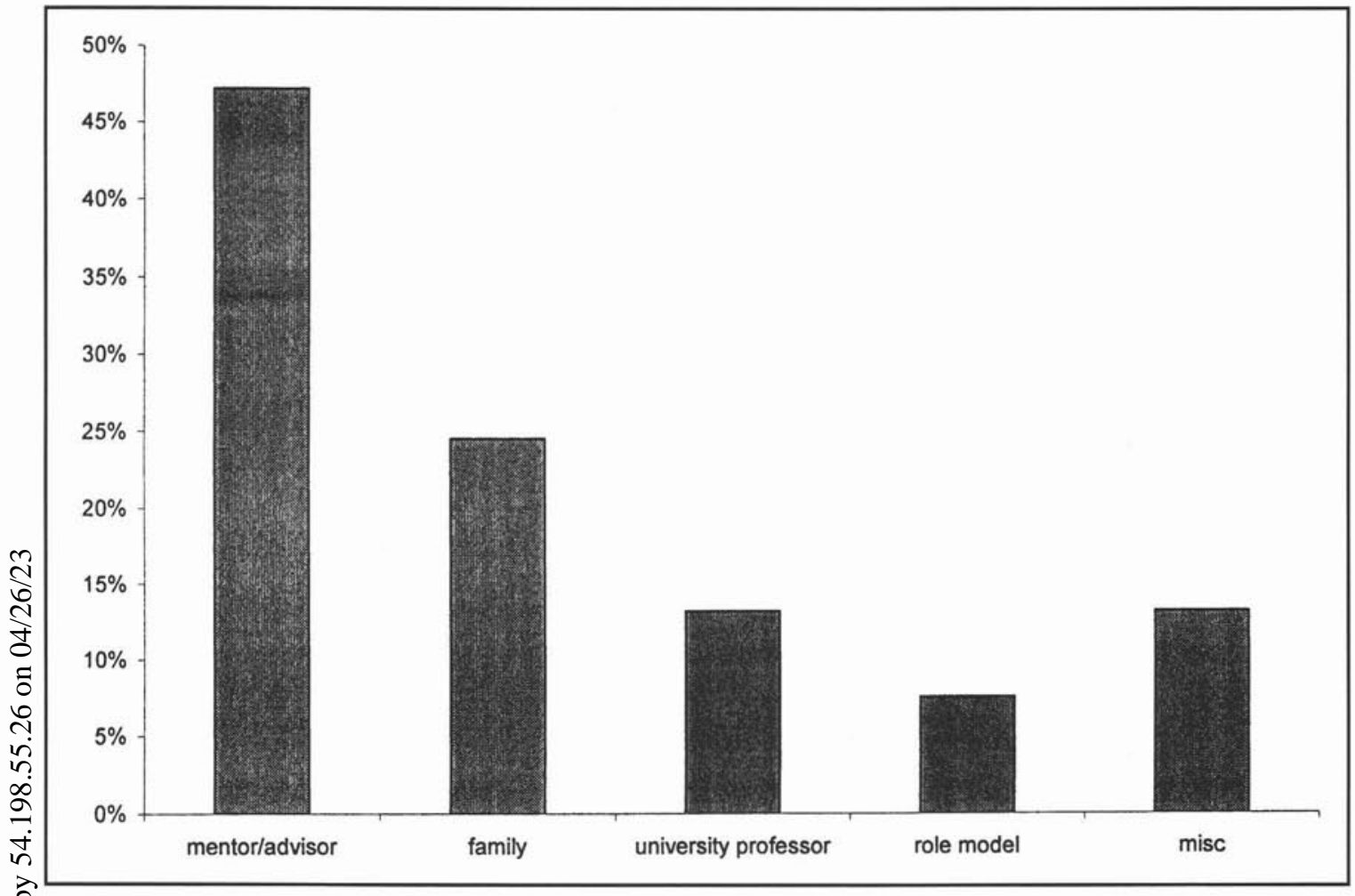

Fig. 3. Most important influences on career path.

influences on their proceeding into and moving through the field of forestry (Fig. 3).

O Most respondents identified the importance of having a menFुor early in their academic endeavours or career. As women g. gined more work experience, although they indicated that they क्षlid not actively seek out mentors, many were selected by a supeIf fior to be mentored, as they had clearly demonstrated their 蛋

Most women interviewed had male mentors, either a risktaking boss, a university professor or a father. As many pointed out, "in the $60 \mathrm{~s}, 70 \mathrm{~s}$ and 80 s we had very few female role models to emulate."

"My Director recognized some potential in me early in my career and took me under his wing," said one respondent. "Initially I followed him around, accompanying him to meetings, preparing advance notes and follow-up actions. But eventua ally he started giving me greater responsibilities and I took over many of his files, lightening his workload, and gradually o accepting more and more responsibility."

Having a male mentor caused problems for some women when it was perceived that issues and perceptions about the relationship moved beyond professional advice. However, even the minority of women who had negative experiences with a male mentor felt they had learned from the experience.

Some women had both male and female mentors throughout their careers, but the lessons learned and advice received from female mentors differed dramatically from those learned from male mentors. Male mentors tended to provide advice on how to "get ahead in a man's world," advice on career advancement and development of technical and management skills.

"I had a female coach when I was in high school who focussed on me as a whole person, not just my athletic endeavours," said one respondent. Many others said they were taught important lessons by their mothers, aunts or grandmothers, who told them if they worked hard they could "have it all"-career, family and personal accomplishment. Still others were fortunate to find women mentors in the university environment that challenged them to "stick it out" despite the fact they were outnumbered sometimes ten to one in the classroom by male students. Another respondent said her mentor "inspired me to view all doors as opportunities."

Risk-taking bosses were seen to have "great courage" for appointing women in positions of higher responsibility. In fact, one respondent indicated that her boss was congratulated for taking the risk of moving her into a higher level position.

Perhaps not surprisingly, those women who benefited from having a mentor in their lives have chosen to mentor others in return. Many have chosen to provide this mentorship to other young women with potential. "Quite frankly, young men do not take easily to having a women provide advice, even if the woman is their boss. It's been my experience that men seek out other males for a mentor, while women are more inclined to seek other women as role models." Others felt it was important to be there as role models for young women since they were lacking during their own personal search for growth and advancement.

\section{Findings: Barriers}

Fully three-quarters of those surveyed had encountered barriers to their success along the way, (Fig. 4). Many said the barriers still exist and they are still encountering them in the year 2001.

While women continue to be under-represented in all facets of the forest sector, those who chose to study or follow a career in forestry in the 70 s and 80 s had few women role mod- 


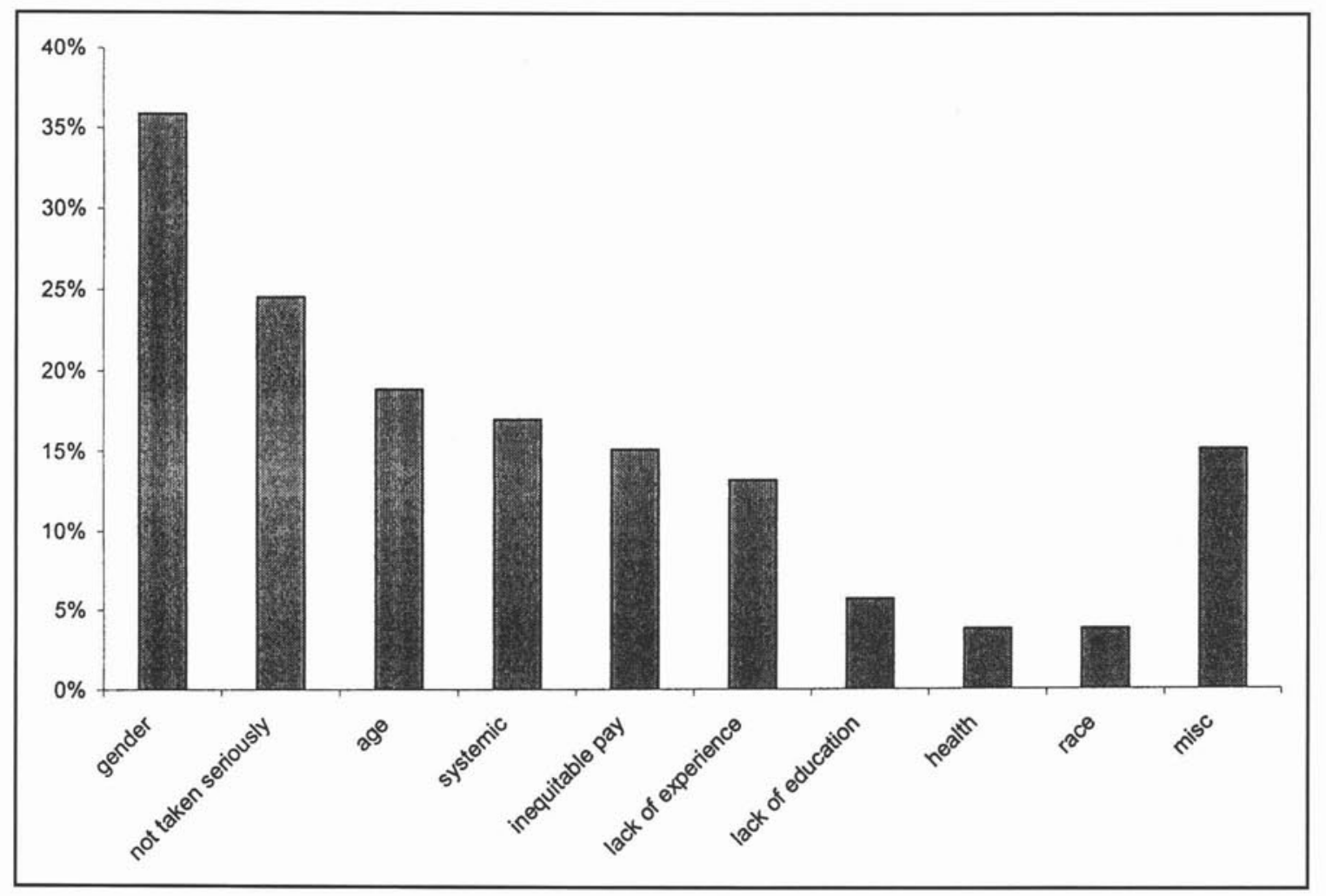

Fig. 4. Factors that represented barriers to success.

els to emulate or call upon for support. One respondent in her $40 \mathrm{~s}$, who is an associate professor at a Canadian university, said that she had no women professors while studying for her undergraduate degree. The lack of women role models often stifled the imagination of where women could go and what they could achieve. These days there are more women role models.

In general, Canada has moved into an employment equity era, where fairness in the workplace and hiring procedures are being adopted, at least nominally, by many companies and the public sector (Wilson 1997). The truth is, according to our respondents, many employers do not "walk the talk"- that is, although they may have employment equity programs and targets in place, they do not always adhere to them.

Still others feel that employment equity can work against women. More than one woman said that hiring someone to meet a quota did not always mean the most qualified was hired. This practice not only hurts employers because they do not hire the best person for the job, but it also hurts the women hired because it is difficult to succeed when people are hired for the wrong reasons.

Women continue to face barriers in obtaining higher levels of education. For some, it is an issue of balancing family commitments against educational goals; for others, it is a financial issue. For those choosing to enter a field dominated by men such as forestry, greater degree of determination is required than in other disciplines.

Some said that although women often have to choose between family and career, men are not confronted with having to make a similar choice. Some women indicated that they had taken time out to raise their families, which put them at a disadvantage in their careers. Yet others felt that one could have both career and family - the issue was a matter of bal- ance. An issue for the next generation will be the add dimension of both spouses having progressive career paths. This will impact the mobility of the individuals to move to new positions. Care for elder parents was identified by the women aged 50 and over as the next hurdle and potential barrier.

"The primary female role models for most men who sit around the boardroom tables are their mothers, their wives and their sisters," said one respondent. "If women continue to be under-represented in most of the professional occupation groups, and men see us as mirror images of their family members, men will continue to see women in the care-taking role and defer to women at meetings to the take the minutes, organize the meetings and arrange the social agendas. As such they will continue to hire and replace themselves with people who look and think like they do-other men."

The values of networking were cited by many. But several women felt they did not have the time to commit to networking, because of career and family obligations. As one respondent said, "....it is far easier for men to find time for power lunches and dinner meetings than for women. Not many of my male colleagues use their lunch hour for family-related appointments or grocery shopping."

On the positive side, many women said that men are becoming more sensitive to the balancing that women often have to perform between career and family and make adjustments, such as reducing travel requirements and being less strict about adhering to timelines at the end of the day.

When questioned on the issue of whether or not women feel they are treated equitably on the pay scale, $39 \%$ of those surveyed felt they were not being paid equivalent to a male colleague for a comparable job. Gender earning differentials provides an important benchmark for gauging the progress of women. 


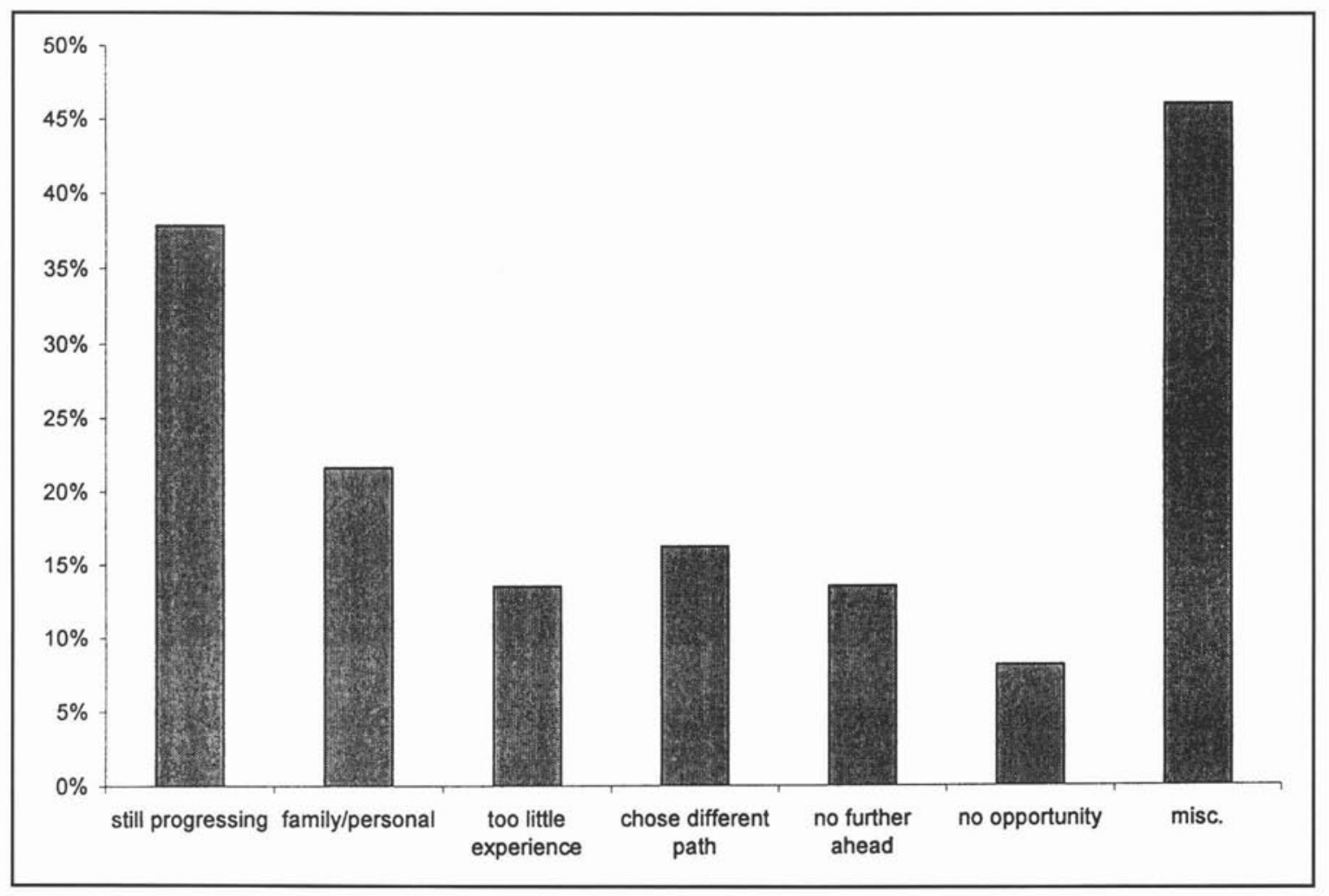

Fig. 5. Reasons why women are not at their anticipated level of career.

Respondents said that pay was the same, regardless of gender, in both government and consulting, but this was not necessarily the case in academia and industry.

According to a study by Derek Aldridge (1997), in Canada the average income for women in 1991 was only $70 \%$ of that for men. Eight years later, in 1999, it had only risen to $73 \%$. Can this gap be explained by educational differences? The answer was no. Even when researchers compared men and women with the same education level, the wage gap remained. Canadian statistics show that women with university degrees earn only $72 \%$ as much as Canadian men with equivalent degrees.

So, what happens when education and experience are factored into the earning differential issue? Aldridge's study also examined the question of whether men and women with the same education and same work experience in the same jobs earned the same remuneration. Men and women who graduated from Canadian universities in 1982 with the same degrees and the same subsequent work history were surveyed, comparing their annual incomes two and five years after graduation. Even when factoring in education and experience, women graduates were earning $88 \%$ as much as men after two years, and only $82 \%$ as much as men after five years. On average, the gap actually increased as careers progressed, according to this study.

Younger survey respondents, not surprisingly, identified lack of experience and expertise as barriers to progression. However, they also acknowledged that they wanted to be recognized for their skills and abilities, rather than be hired as part of employment equity programs.

Of the $25 \%$ of women who responded that they had not encountered any barriers, most said that they had chosen to look at the issue as an opportunity rather than a as barrier, choosing to challenge the status quo.
The good news is that despite the fact $75 \%$ of the survey respondents indicated that they had encountered barriers along the way, some $87 \%$ indicated that they felt successful. Nearly $80 \%$ of the respondents said it was easier to get ahead in the $90 \mathrm{~s}$ than previously. The bad news is that despite improvements, the struggle continues. However, women are more determined than ever to overcome the barriers. Perseverance was identified as the second-most important factor in achieving success, with performance being ranked as the most important.

\section{Findings: Choosing a Non-Traditional Path}

Nearly two-thirds of survey respondents said they had not identified a career path for themselves when they entered into post-secondary education. Many indicated that timing and personal or family commitments were significant factors deterring them from identifying a path. Several indicated that they could not have imagined the opportunities that lay before them when choosing to enter the field of forestry (Fig. 5). A few said there was no work in their chosen field when they started out, while others said they had to seek out opportunities themselves. Several women indicated that it was a combination of luck and timing that finally landed them jobs in the forest sector.

Many of the women interviewed were "children of the 60 s generation" who tended to challenge the status quo and look at a position in management with disdain, rather than one to which to aspire. As one respondent said, "I never thought about being a manager because to me when I was setting my sights on a career, management represented control. I set my sights on collective and social change, certainly not leading an organization." Many were encouraged to direct their energies toward the traditional fields of research, operations and working in the woods. 


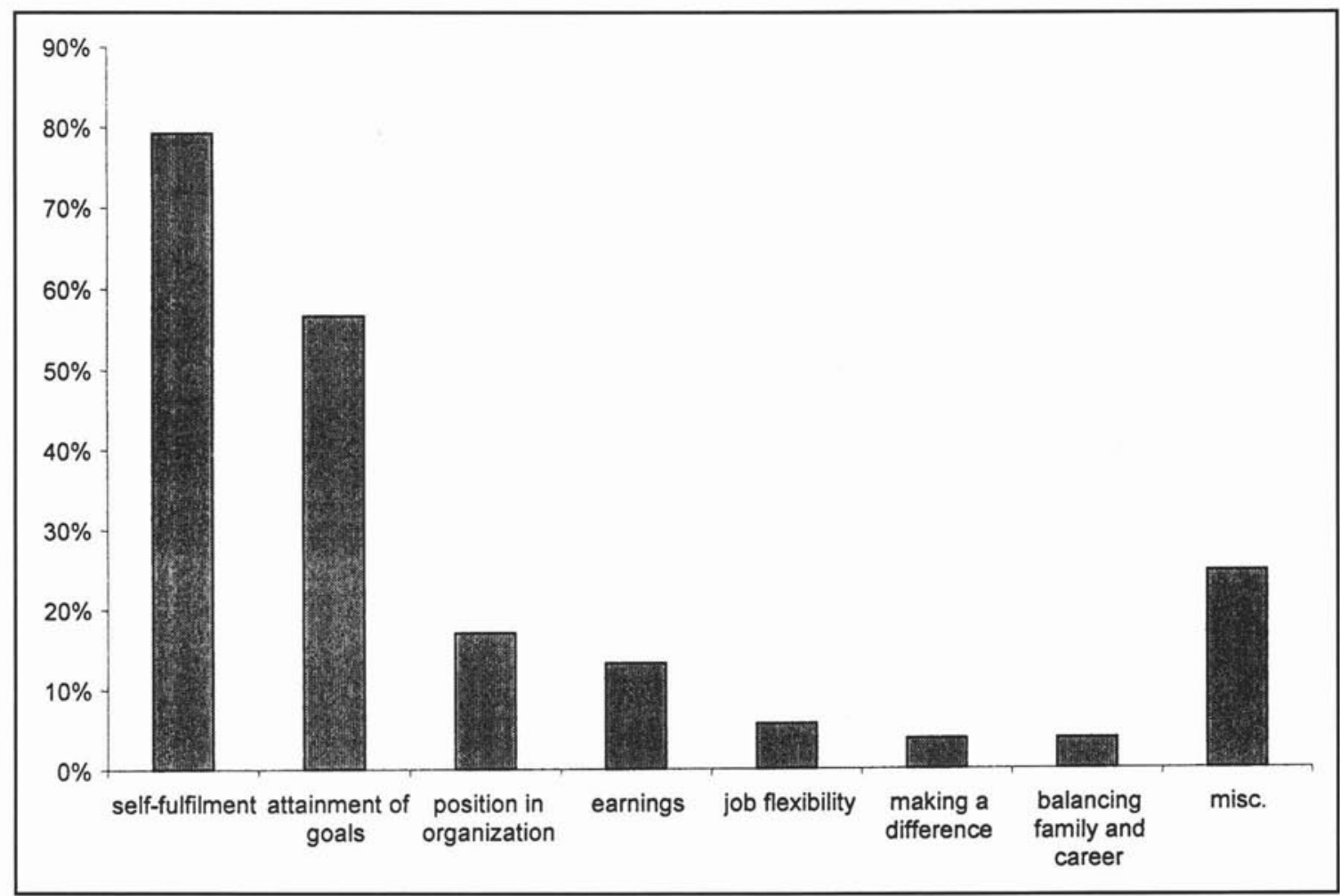

Fig. 6. How women define success.

Fig. 7. The most important influences on a woman's career.

When asked if they feel successful today, $87 \%$ responded in the affirmative. Nearly $80 \%$ of respondents defined success in terms of self-fulfilment, followed closely by attainment of personal goals. Position within an organization and earnings were far less important to women in defining success (Fig. 6).
The respondents who considered themselves successful indicated that their success was due to their management style: building dynamic and participatory teams within their organizations and empowering staff. In addition, they felt they had good inter-personal skills, which they used to influence change via the team approach and through consensus building. 
On average, it took most women between five and ten years of work to advance from either entry level to midcareer or from mid-career to a senior position. For a few women, mainly those working in academia, it took over 10 years to advance from one level to another, especially at the entry to mid levels.

When women were asked to rank the single-most important influence on their careers to date, they overwhelmingly said it was a willingness to take risks (Fig. 7). Nearly half the women said personal willingness to test their limits, take on new opportunities and challenge themselves, were the most important reasons for advancement. Others said education was the most important factor (20\%), followed by family support $(14 \%)$ and the impact of a mentor (12\%).

The women were asked to rate the importance of belonging to a professional association in terms of career advancement. Slightly less than half, or 47\%, said it was important to belong to such a body. Those who responded in the affirmative said the most important reasons for doing so were to contribute back to the sector and to make contacts. A smaller number said they belonged to professional associations to enhance either the reputation of their employer or their own.

\section{Conclusion: Future Looks Brighter}

In spite of the challenges of access to the sector, the numbers of women entering natural resource management is rising. The Canadian women interviewed are optimistic that the path to positive employment and career advancement is clearer now than ever before, made easier by those who have gone before them and the improvements in public attitudes on traditional employment.

It is clear that although women continue to be underrepresented in the woods, in the university classroom, in teaching, in operations, in senior government positions and in the corporate boardrooms, this is changing.

Nearly $80 \%$ of the respondents said they were optimistic that great strides had been made in the 90s and the future looked equally bright moving into the new millennium. In particular, respondents felt it is possible for women to have a successful career and a happy family life. They acknowledge that it will take extra effort to balance the two but that it is an effort they are willing and prepared to accept. This task is made easier by the fact that there is a growing enlightenment that both men and women are seeking positive balance in their lives and careers.

Education, both formal and continuing, is critical in reaching positions of influence in the Canadian forest sector. As the challenges of making decisions about the sector have increasing global implications, having the brightest and most innovative talent is vital to employers. Respondents acknowledge that competition in the workplace is increasing and they say that they are prepared to invest more time in formal education than women did in previous decades, in order to secure positions of influence.

The increased numbers of women in the forest sector means there are more and more role models for young women to emulate. These women have a wide range of experience: operations; middle and senior management; policy development; academia and consulting. This widens the opportunities for all women in the sector.

Finally, most of the respondents agreed that having both men and women working together, equally valued for their contributions, is the best approach to tackling the challenges the natural resource sector faces.

It is perhaps fitting, therefore, that we end with a quote by Elizabeth Perle McKenna, an American author and champion of women's rights in the workplace: "If it is true that men today value their lives outside of work as much as women do-and research proves it is - then they have to join women's fight to reconstruct the way we work and create a new, broader definition of success."

\section{Acknowledgements}

The authors wish to thank the 53 women who participated in this survey and in subsequent interviews. Without their input, this paper would not have been possible. Their willingness to respond to our questions indicates a strong desire to make the workplace more inclusive for all. They are all role models in the truest sense.

\section{References}

Atkinson, A. and M. MacIvor. 2000. Aboriginal Women in Forestry: barriers, challenges and benefits. FORUM, Sept/Oct.: 22-27.

Aldridge, D. 1997. Using Male Earnings Data to Forecast the Future Income of Females. Economica Ltd. Newsletter 2(3) at website www.economica.ca viewed_January 2001.

Human Resources Development Canada. 2001. Job Futures 2000. At website www.hrdc-drhc.gc.ca viewed January 2001.

Lalonde, J.C. 1993. Walking on Broken Glass: Success Strategies of Women Executives Who Have Broken Through the Glass Ceiling of the Public Service of Canada. Masters of Business Administration Research project. University of Ottawa.

Marchak, P. 1983. Green Gold: The Forest Industry in British Columbia. University of British Columbia Press, Vancouver, B.C.. Natural Resources Canada. 1998. Women in Forestry. In State of Canada's Forests, 1997-1998. pp. 74-79. Canadian Forest Service, Ottawa, Ontario.

Statistics Canada. n.d. At website www.statcan.ca. viewed December 2000 .

Wilson, T. 1997. Diversity at Work: The Business Case for Equity. John Wiley \& Sons Canada Ltd., Toronto, Ontario. 